\title{
Mezi praxí a teorií v učitelském vzdělávání: na okraj českého překladu knihy F. A. J. Korthagena et al.
}

\author{
Jan Slavík, Tomáš Janík, Petr Najvar, Michaela Píšová
}

Masarykova univerzita, Pedagogická fakulta, Institut výzkumu školního vzdělávání

Redakci zasláno 3. 6. 2012 / upravená verze obdržena 4. 9. 2012 / k uveřejnění přijato 8. 9. 2012

\begin{abstract}
Abstrakt: Text je koncipován jako teoretická studie vycházející v návaznosti na český překlad knihy Linking practice and theory: The pedagogy of realistic teacher education od F. A. J. Korthagena et al. Výklad je ve studii rozvržen do dvou částí. V první části jsou představeny vůdčí (programové) myšlenky Korthagenovy koncepce; text je převážně popisný, nemá ambici kritické analýzy. 0 to jde $\mathrm{v}$ druhé části studie, kde se autoři vracejí k vybraným myšlenkám Korthagenovy koncepce, rozebírají je a podrobují je diskusi v širším kontextu novějších domácích i zahraničních přístupů a poznatků. Zaměřujíse na tři související problémové okruhy: (1) Povaha vztahu teorie a praxe - nedocenění Teorie s velkým T? (2) Význam reflexe $v$ učitelově profesním rozvoji - vyprázdněnost s ohledem na učivo? (3) Podpora profesního učení redukované pojetí supervize? V závěru studie je otevřena otázka, jak prezentovanou koncepci využít v kontextu učitelského vzdělávání v České republice.
\end{abstract}

Klíčová slova: praxe, teorie, učitelské vzdělávání, reflexe, výuka, supervize

\section{1 Úvodem}

V českém překladu knihy Freda Korthagena a spolupracovníků (2011) se čtenáři po deseti letech od svého původního vydání (2001) dostává do rukou kniha, která nabízí inspirativní pohled na vztah praxe a teorie v učitelském vzdělávání1. Text je syntézou předchozích prací autorů a jeho unikátnost spočívá $\mathrm{v}$ tom, že představuje ucelenou koncepci učitelského vzdělávání. Ta staví na solidních základech a explicitně formulovaných pedagogických a psychologických východiscích a zároveň se v mnohém liší od tradičních a dodnes široce realizovaných přístupů k učitelskému vzdělávání.

\footnotetext{
Překlad a vydání knihy byly podpořeny finančními prostředky z projektů MŠMT LC 06046 Centrum základního výzkumu školního vzdělávání a Výzkumného záměru MSM0021620862 Učitelská profese $v$ měnících se požadavcích na vzdělávání. Tato studie je výstupem z řešení druhého z výše zmíněných projektů; její autoři měli možnost zhostit se rolí překladatelů, lektorů a konzultantů knihy, která vyšla pod názvem Jak spojit praxi s teorií: Didaktika realistického učitelského vzdělávání v roce 2011 v brněnském nakladatelství Paido.
} 
Českému čtenáři jsou dílčí Korthagenovy práce známy především díky starším publikacím českých a slovenských autorů (Švec, 1999; Lukášová-Kantorková, 2003; Spilková et al., 2004; Janík, 2005; Píšová 2005; Kasáčová, 2006 ad.) a jeho myšlenky nacházejí odezvu i dnes (Spilková \& Vašutová et al. 2008; Janík \& Minař́́ková et al., 2011; Píšová \& Duschinská et al., 2011; Maňák, 2011; Minaříková \& Janík, 2012; Višňovský, Pupala, \& Kaščák, 2012 v tomto čísle Pedagogické orientace a další). Pře(d)ložením celé Korthagenovy knihy se poprvé nabízí př́ležitost seznámit se s celou koncepcí didaktiky realistického vzdělávání učitelů včetně jejích filozofických a psychologických východisek a důsledků pro praxi vzdělávání učitelů.

Uspořádání knihy sleduje hlavní myšlenku o propojování praxe $\mathrm{s}$ teorií. Kapitoly označené lichými čísly předkládají základní principy představované koncepce z praktického hlediska. Sudé kapitoly naopak popisují teoretická východiska, konceptualizace klíčových pojmů a také nálezy empirického výzkumu zaměřeného na evaluaci prezentované koncepce. Čtenáři zajímajícímu se jen o praktické souvislosti se tak nabízí možnost přečíst si jen „liché“ kapitoly, naopak čtenář pátrající po teoreticko-výzkumných souvislostech by se mohl spokojit jen s kapitolami „sudými“. Takoví čtenáři - jak upozorňuje Korthagen - by však byli ochuzeni o to nejdůležitější, co kniha přináší, tj. o nový pohled právě na spojení praxe s teorií.

\section{Vůdčí ideje Korthagenovy koncepce}

$\mathrm{V}$ této části stručně představíme vůdčí (programové) ideje Korthagenovy koncepce, jak je zachycuje kniha. Postupně budeme spolu s Korthagenem a jeho spoluautory věnovat pozornost metafoře technické racionality, inspiracím realistickou výukou matematiky, dvojí modalitě vědění - epistémé versus fronésis, pohybu od praxe $\mathrm{k}$ teorii, roli reflexe, roli gestaltů, procesu supervize, vybraným principům nové didaktiky učitelského vzdělávání a problematice přípravy vzdělavatelů učitelů na tuto koncepci. Následující text je převážně popisný, nemá ambici kritické analýzy; k té se dostáváme dále (kap. 2).

\subsection{Model technické racionality}

Korthagen a kolektiv staví svoji koncepci realistického učitelského vzdělávání na kritice aktuálně dominantního (tradičního) pojetí učitelského vzdělávání. Na ně se v knize odkazuje pod programovým názvem: model technické racio- 
nality (Schön, 1983). Tradiční model učitelského vzdělávání podle autorů očekává od studentů učitelství, že se naučí, jak aplikovat v praxi teorii kvalitní výuky, se kterou se seznámili v učitelské přípravě. Tento model předpokládá, že učitelé uplatní vědecké pedagogické, psychologické a další teorie (získané skrze formální učitelské vzdělávání) ve své každodenní praxi na školách.

Model technické racionality dominuje učitelskému vzdělávání napříč Evropou i severní Amerikou po několik dekád. Tento přístup však podle Korthagena et al. nefunguje, a to hned z několika důvodů. Mimo jiné zde působí fenomén, který někteří autoři nazývají šok z přechodu do praxe (Hinsch, 1979; Dann, Müller-Fohrbordt, \& Cloetta, 1981), který způsobuje, že v průběhu prvního roku po ukončení studia učitelství se postoje začínajících učitelů proměňují a určitým způsobem přizpůsobují stávajícím praktikám ve škole. Zeichner a Tabachnick (1981) hovořív této souvislosti o fenoménu vymytí progresivních prrístupů v postojích začínajících učitelů.

Jiným důvodem selhávání modelu technické racionality je fakt, že vytváří určitou propast mezi teorií a praxí. Z výkladu autorů (Korthagen et al., 2011, zde viz kap. 1.3) však vyplývá, že hlavním problémem není samotná propast, ale fakt, že z jejího vzniku a rozšiřování se navzájem obviňují učitelé a jejich vzdělavatelé. Zatímco vzdělavatelé učitelů chtějí, aby učitelé „velkou“ teorii do praxe aplikovali lépe, pro učitele se pod tíhou každodenních problémů stává aplikování teorie nesplnitelným úkolem. Aby se začínající učitel zbavil pocitu trvalého selhání, osvojí si postoj, jenž je mezi učiteli velmi rozšířený, že totiž učitelské vzdělávání je př́liš teoretické a pro praxi neužitečné. Z vytvoření propasti mezi teorií a praxí tak vlastně viní vzdělavatele učitelů.

\subsection{Inspirace realistickou výukou matematiky}

Jako inspirace pro možnou změnu pojetí učitelského vzdělávání slouží Korthagenovi a jeho spolupracovníkům koncept tzv. realistické výuky, který byl v 80. letech 20 . století rozvíjen ve výuce matematiky. Tradiční výuka matematiky vychází od teorie (pravidla, principy) a staví na jejich aplikaci do praxe, což není nepodobné tomu, jak funguje model technické racionality v kontextu vzdělávání učitelů. Jenže výsledky výzkumů ukazují, že se tímto způsobem žáci nenaučí transferovat své znalosti získané řešením početních úloh dle stanovených postupů do řešení každodenních situací mimo výuku. 
Koncept realistické výuky matematiky staví na opačném postupu než tradiční výuka matematiky. Korthagen et al. citují Freudenthala (1978, s. 72), podle kterého matematika není vytvořeným předmětem, který je třeba žákům předat, ale předmětem, jenž má být (žáky) vytvářen tak, že budou aktivně bádat a prakticky matematiku používat. $\mathrm{V}$ prostředí realistické výuky matematiky si žáci rozvíjejí své matematické představy na základě praktických zkušeností a problémů, jež jsou jim prezentovány v jim blízkém kontextu.

\subsection{Epistémé versus fronésis}

Extrapolací principů realistické výuky do učitelského vzdělávání formulují Korthagen a jeho spolupracovníci koncepci, jejíž těžiště spočívá v aktivní práci studentů učitelství s jejich zkušenostmi s výukou a která pracuje s odlišným pojetím teorie než model technické racionality. Jak podrobněji ukazujeme dále, právě pohled na povahu teorie představuje jeden z významných rozdílů mezi tradičním a realistickým přístupem k učitelskému vzdělávání.

Tento rozdíl je ilustrován s oporou o odlišné pohledy na znalosti (vědění) reprezentované antickými mysliteli Platónem a Aristotelem. Platónovo pojetí znalostí jako epistémé, na němž postaveno tradiční učitelské vzdělávání, modeluje vědění jako strukturu obecných tvrzení, jež pracují s abstraktními pojmy a vztahy mezi nimi. Tato struktura představuje teorii, která má - aplikovaná do konkrétního kontextu - potenciál popisovat, vysvětlovat a predikovat fenomény reálného světa. Naproti tomu Aristotelovo pojetí znalostí jako fronésis, s nímž pracuje realistické učitelské vzdělávání, vidí vědění jako praktickou moudrost, která staví na znalosti konkrétních kontextově vázaných jednotlivostí.

\subsection{Od praxe $k$ teorii}

Pro učitelské vzdělávání znamená orientace na fronésis přesun akcentu na praktické zkušenosti studentů učitelství, které se stávají východiskem pro jejich učební proces. V jistém smyslu se tím také obrací gard; zatímco v tradičním modelu se postupuje od teorie skrze její aplikaci k praxi, v realistickém modelu se jde cestou od praktických zkušeností k budování vlastních konceptuálních schémat, které osvětlují praxi a poskytují předpoklady spojit ji s teorií.

Toto obrácení gardu má zdánlivě závažné důsledky pro vytváření kurikula učitelského vzdělávání. Zatímco v tradičním modelu tvoří obsah kurzů v pro- 
gramu učitelského vzdělávání vzdělavatel tím, že vybírá relevantní teorie a o nich potom přednáší studentům, $\mathrm{v}$ realistickém modelu se vychází $\mathrm{z}$ reálných zkušeností studentů učitelství z výuky a z jejich aktuálních potřeb těmto zkušenostem účelně porozumět. Na první pohled by se tedy mohlo zdát, že obsah takových kurzů je svou povahou nahodilý a nepředvídatelný. Tak tomu ovšem není. Posun od tradičního k realistickému modelu spíše přináší fundamentální změnu role vzdělavatele učitelů. Ten v novém modelu zadává studentům odcházejícím na praxi do škol takové úkoly, které v nich s určitou pravděpodobností podnítí uvažování o výuce a potřebu (concern) o ní diskutovat po návratu do univerzitní posluchárny. Ve skutečnosti se tedy obsah učitelského vzdělávání v realistickém modelu nemění, je jen poněkud jinak strukturován. Vzdělavatel učitelů jej totiž nepřináší přímo a podle logiky Teorie s velkým $T$, ale spíše způsobuje, že jej přinášejí sami studenti učitelství ze svých zkušeností z praxe (je tedy strukturován spíše podle logiky teorií s malým $t$ ).

\subsection{Role reflexe}

$\mathrm{V}$ realistickém modelu je jedním z klíčových pojmů reflexe. $\mathrm{V}$ realistickém programu učitelského vzdělávání prochází student učitelství (at’ už samostatně, nebo za pomoci supervizora/mentora) fázemi procesu reflexe, které vystihuje tzv. model ALACT (fáze jednání, fáze zpětného pohledu na jednání, fáze uvědomění si podstatných aspektů, fáze vytvoření alternativních postupů jednání, fáze vyzkoušení, která je totožná s první fází nového cyklu).

Prostředí, ve kterém student učitelství své zkušenosti s výukou reflektuje, musí splňovat několik požadavků, $\mathrm{z}$ nichž nejdůležitějším je požadavek na vyváženost mezi náročností úkolu, který student učitelství plní, a pocitem bezpečí, který ve studentu toto prostředí vyvolává. Pokud se učící se jedinec nepohybuje v prostředí, jež v něm vyvolává pocit bezpečí, jsou učební procesy tlumeny fenomény jako starost o přežití (Fuller \& Bown, 1975) či rezistence vưči změně.

Korthagen et al. (2011, s. 85n., 196) navrhují metodicky zajistit pocit bezpečí tím, že studenti učitelství v praxi nejdříve absolvují individuální výuku (the one-to-one), teprve pak běžnou výuku s celou tř́dou žáků. Individuální výuka je monitorována videozáznamem a probírána v reflexi, která po výuce následuje. To studentům umožní uvědomovat si svoje postupy a zamýšlet se nad nimi v neohrožujícím prostředí. 
Jedním z výsledků výzkumných studií, které byly v souvislosti s koncepcí realistického učitelského vzdělávání provedeny, je soupis čtyř charakteristik, jež vykazují tzv. reflektivní učitelé. Mezi tyto charakteristiky patří např. schopnost adekvátně popsat a analyzovat své fungování v interpersonálních vztazích s druhými. Reflektivní učitel je také schopen vědomě strukturovat situace a problémy a považuje tuto činnost za dủležitou. Vedle těchto charakteristik autoři nalezli také několik tzv. korelátů reflektivity, jako jsou napřs: reflektivní učitelé mají silný pocit osobního bezpečí a vlastní zdatnosti v učitelství, či reflektivní učitelé mají lepší interpersonální vztahy se žáky než jiní učitelé.

\subsection{Role gestaltů}

Korthagenova koncepce, vedle toho, že přináší nové pojetí učitelského vzdělávání včetně konkrétních návodů, jak na něm vystavět program učitelského vzdělávání, je cenná tím, že v sobě obsahuje explicitní teorii profesního učení. Podle ní řídí rozhodování učitele $\mathrm{v}$ reálných situacích vnitřní entity - gestalty, jež jsou směsicí „zájmů, potřeb, hodnot, významů, preferencí, pocitů a tendencí $\mathrm{k}$ jednání jedince, spojených $\mathrm{v}$ jeden nedělitelný celek" (Korthagen et al., 2011, s. 56).

Tyto gestalty, týkající se procesů učení, vyučování, typologií učitelů a žáků, se často utvářely $\mathrm{v}$ době, kdy byl student učitelství ještě sám žákem ve škole. Důvodem, proč má tradiční formální učitelské vzdělávání jen velmi omezený vliv na reálnou praxi učitelů, je to, že se mu nedaří do těchto gestaltů proniknout tak, aby se mohly přednášené teorie stát jejich součástí a tím ovlivňovat učitelovo rozhodování ve výuce. Jen skrze reflexi může učitel své gestalty analyzovat, zexplicitnit ${ }^{2}$, a jejich elementy pak vidět $v$ novém kontextu.

Postupu od neuvědomovaných gestaltů $\mathrm{k}$ uvědomělému porozumění ř́ká Korthagen schematizace. Proces schematizace u subjektu vede k utváření schémat, což jsou soubory poznatků o určitých charakteristických vlastnostech gestaltů. „Proces schematizace lze často podpořit tak, že člověk hovoří o tom, co vidí, o čem přemýšlí a co dělá a podrobněji zkoumá to, co bylo samo o sobě zcela zřejmé" (Korthagen et al., 2011, s. 179). Prostřednictvím schematizace se u studentů učitelství utvářejí mentální struktury nové povahy, více kognitivní než afektivní, a více uvědomované, kterým Korthagen

2 Slova zexplicitnit, zexplicitňovat, či zexplicitnění mohou českému čtenáři znít jako výsledek neobratného ohýbání cizího slova. V překladu knihy jsou však běžně používána, nebot' dobře vystihují původní význam v anglickém jazyce. 
ř́ká teorie s malým $t$ (čímž je vymezuje vůči Teoriím s velkým $T$, což jsou vědecké teorie abstraktní, intersubjektivní povahy). Synonymem pro teorie $\mathrm{s}$ malým $t$ je termín subjektivní teorie.

Uvedený proces chápe Korthagen jako vývoj učitelových znalostí rozvržený do třech základních výše popsaných úrovní: utváření gestaltů, schematizace, budování teorie (viz dále model GST). „Během utváření gestaltů se dotyčný zaměřuje (často nevědomky) na to, jak jednat v určitých situacích; při schematizaci se vědomě snaží ujasnit si gestalty; a při budování teorie je cílem zavést do schémat logický řád" (Korthagen et al., 2011, s. 188). Při postupu mezi jednotlivými úrovněmi dochází nejprve k růstu objemu získaných informací uvnitř určitého způsobu porozumění, pak v určité fázi tohoto vývoje dojde k restrukturaci poznání a k přechodu do vyšší úrovně porozumění.

Koncepčně důležitý je Korthagenův koncept tzv. redukce úrovně. Ten spočívá $\mathrm{v}$ tom, že systematičtější a uvědomělé znalosti z vyšší úrovně se mohou stát organizujícími činiteli jednání v neuvědomované, intuitivní podobě. Tak se teorie s malým $t \mathrm{v}$ procesu redukce úrovně časem opět stávají gestalty rúdícími učitelovo jednání. Tyto gestalty však již nejsou produktem nahodilých anekdotických zážitků z dětství anebo náhodně posbíraných profesních zkušeností, ale disciplinovaného uvažování nad reálnými praktickými situacemi.

V souvislosti s redukcí úrovně je vhodné zmínit ještě jeden moment, klíčový pro učitelské vzdělávání: kvalita teorie, ze které se odvíjí redukce. Korthagen upozorňuje (2011, s. 189), že subjektivní teorie (teorie s malým $t$ ) jsou jen „lokální“, uzpůsobené místním podmínkám a subjektivně omezeným zkušenostem jednoho učitele. Proto mohou být $\mathrm{v}$ rozporu s obecněji uznávanými Teoriemi s velkým $T$. Tím je navozena poměrně palčivá otázka vzájemných vztahů mezi subjektivními a „velkými“ teoriemi. K této otázce se níže vrátíme, protože Korthagen ji v knize sice otevírá, ale do větší hloubky nerozebírá.

\subsection{Proces supervize}

Jak již bylo uvedeno výše, student učitelství neprochází jednotlivými fázemi procesu reflexe sám; alespoň zpočátku ne. U mnoha studentů učitelství musí dříve, než jsou schopni začít uvažovat reflektivně, dojít k procesu, který Korthagen nazývá „převzetí zodpovědnosti za vlastní učení“ (Korthagen et al., 2011, s. 116). Teprve poté jsou schopni porozumět nové roli vysokoškolských učitelů (viz kap. 1.4), kteří jsou v nové koncepci méně přednášejícími, a více 
supervizory. Hlavním posláním supervizora je napomoci studentu učitelství projít jednotlivými fázemi modelu ALACT.

Aby toto poslání naplnil, potřebuje supervizor podle Korthagena disponovat některými specifickými supervizními dovednostmi. Mezi ně patří dovednost rozpoznat, jaký druh pomoci je aktuálně zapotřebí, tzn., ve které fázi reflektivního cyklu se student učitelství zrovna nachází. Zatímco v určitých fázích je nutné, aby supervizor dokázal projevit akceptaci a empatii, v jiných fázích je třeba stavět na konfrontaci či zobecňování. Mezi další dovednosti, kterými má supervizor disponovat, jsou autenticita či dovednost ve správném okamžiku mlčet.

Učitelské vzdělávání lze ovšem jen málokdy realizovat formou individuální supervize. Proto je v Korthagenově koncepci vedle individuální supervize zvláštní pozornost věnována i supervizi skupin studentů učitelství. Jedním z důležitých nástrojů, které se při skupinové supervizi uplatňují, je deník.

\subsection{Tři principy nové didaktiky učitelského vzdělávání}

S oporou o toto pojetí profesního učení formulují Korthagen et al. (2011, s. 84) tři principy nové didaktiky učitelského vzdělávání: (1) Vzdělavatel by měl pomoci studentu učitelství, aby si uvědomil své učební potřeby. (2) Vzdělavatel by měl pomoci studentu učitelství nacházet užitečné zkušenosti. (3) Vzdělavatel by měl pomoci studentu učitelství tyto zkušenosti detailně reflektovat.

Korthagenův text implicitně staví na konstruktivistických teoriích vzdělávání, které nedogmaticky využívá pro vzdělávání učitelů. Konstruktivistický př́stup se projevuje již v základním nároku vycházet ze studentovy profesní zkušenosti, která má být tematizována a podrobena zkoumání v odborném dialogu uvnitř kolegiální skupiny a pod dohledem supervizora. Ve stejném duchu vyznívá i výzva nepředávat „hotové“ poznatky, ale opírat profesní znalosti o vlastní experimentaci s poznávanou realitou ústící až do systematické podoby akčního výzkumu (model ALACT). Také důraz na komplexní přístup k profesionální zkušenosti, s poukazem na její hodnotovou, emoční a motivační stránku, souzní s konstruktivistickým ohledem k subjektivnímu východisku poznávání.

Autorům představujícím novou koncepci (učitelského vzdělávání) hrozí nebezpečí, že jejich myšlenky budou některými kritiky odmítány s tím, že jde 
o práci akademiků bez opravdové zpětné vazby z reálné praxe. Korthagenův autorský tým tomuto nebezpečí čelí tak, že současně se svou koncepcí přináší výsledky čtyř empirických studií, jež byly provedeny s cílem evaluovat realizované realistické programy učitelského vzdělávání. Tyto čtyři studie si kladly různé cíle a využívaly různých výzkumných designů (longitudinální, kvantitativní, komparativní).

\subsection{Př́prava vzdělavatelů učitelů na novou koncepci}

Je zřejmé, že nová koncepce vzdělávání učitelů klade jiné nároky na vzdělavatele učitelů než tradiční vzdělávání učitelů (reprezentované modelem technické racionality). Korthagen et al. proto svou koncepci doplňují o pohled na profesní rozvoj vzdělavatelů učitelů, kteří realistický model realizují. Role, kterou vzdělavatelé v této koncepci hrají, není intuitivní, a autoři proto představují návrh vzdělávacího kurzu, který má pomoci u vzdělavatelů učitelů rozvíjet supervizní dovednosti, a to zejména ty nejdůležitější, jako jsou orientace na vlastní zkušenosti studentů učitelství, konkretizování, vytváření bezpečného prostředí apod.

Vedle přípravy vzdělavatelů učitelů proponují Korthagen et al. také nové př́stupy v empirickém pedeutologickém výzkumu, který nazývají realistickým výzkumem, nebot' by respektoval principy realistického vzdělávání a jejich filozofická a zejména psychologická východiska.

\section{Korthagen jako výzva - kriticko-přátelské ohlédnutí}

Jak je z dosavadního výkladu patrné, Korthagenova kniha vychází ze zřetelně vymezené koncepce založené na dlouhodobém systematickém směřování ke spojení teorie s praxí. Proto její kritické promýšlení a srovnávání s jinými přístupy může být podnětné jak pro teoretické, tak pro praktické využití. Naším cílem je zasadit je mj. do kontextu zdrojů (publikací) autorů pracujících v jiných kulturních kontextech či paradigmatech a nabídnout tak srovnání, které může vést $\mathrm{k}$ novým podnětům. $\mathrm{Z}$ uvedených důvodů se $\mathrm{v}$ dalším textu budeme vracet k vybraným myšlenkám Korthagenovy koncepce a pokusíme se je podrobit kritické analýze. Zaměříme se přitom (1) na povahu vztahu teorie a praxe, (2) na význam reflexe v učitelově profesním rozvoji a (3) na podporu profesního učení. V souvislosti s tím rozebereme trojici problémových okruhů: $(\mathrm{ad} 1)$ nedocenění Teorie s velkým $T$, (ad 2) vyprázdněnost reflexe s ohledem na učivo a $(\operatorname{ad} 3)$ redukované pojetí supervize. 


\subsection{Povaha vztahu teorie a praxe - zdrženlivost $k$ Teorii s velkým T?}

V celkové dikci Korthagenovy koncepce je patrná snaha vyvažovat objem a váhu obou stran v klíčové polaritě teorie vs. praxe. $\mathrm{V}$ modelech ALACT a GST (viz kap. 1.5 a 1.6 a níže v textu) autoři nabízejí metodologický rámec pro cestu k hlubšímu teoretickému porozumění. Zároveň však jsou skeptičtí k Teorii s velkým $T$, není-li doprovázena redukcí úrovně (Korthagen et al., 2011, s. 186). Redukce úrovně je mentální proces, v němž teoretické koncepty anebo komplexní schémata mohou začít fungovat jako gestalt, tj. jako profesionální intuice, která zabezpečuje kvalitní rozhodování a jednání, aniž jeho původce musí př́islušnou situaci př́liš reflektovat a promýšlet.

Redukce úrovně může ovšem vést ke kvalitnímu jednání pouze tehdy, je-li teorie v jejím jádru natolik hodnotná, aby mohla být dostatečně „praktická“ ve smyslu Einsteinova bonmotu „nejpraktičtější je dobrá teorie“. Tohoto hlediska si Korthagen př́liš nevšímá. Možná právě proto čtenář nachází v textu náznaky, že úloha Teorie s velkým $T$ není ujasněna anebo není doceňována $\mathrm{v}$ tom smyslu, že se jí kniha nijak důsledně nevěnuje. Korthagen na více místech přesvědčivě poukazuje na potřebnost teorie s malým $t$, o nezbytnosti Teorií s velkým $T$, akademických teorií, jako by však nebyl přesvědčen, přinejmenším na počátku učitelského vzdělávání: „Je-li tu skutečná teorie v akademickém smyslu slova vůbec na místě..., její čas přichází často až v mnohem pozdější etapě učitelského vzdělávání“ (Korthagen et al., 2011, s. 197).

V této souvislosti pokládáme za vhodné dodat, že již v době, kdy Korthagen se spoluautory své dílo sepisovali, byly k dispozici teorie, které objasňují proces integrace či amalgamizace obecnějších teoretických znalostí s případovými znalostmi z (klinické) praxe (srov. Schmidt \& Boshuizen, 1992). Výklad o vztahu teorie a praxe by zřejmě byl přiléhavější a snad i vstř́ícnější k Teorii $\mathrm{s}$ velkým $T$, pokud by se autoři opřeli o tyto novější studie, které fenomén amalgamizace ilustrovaly v oblasti vzdělávání a profesního vývoje mediků.

Zdrženlivost $\mathrm{k}$ Teorii s velkým $T$ lze nalézt i v jisté skepsi spojené $\mathrm{s}$ dosahováním teoretického stupně reflexe v modelu GST. Korthagen zde při rozboru modelové situace, $\mathrm{v}$ níž respondent dosáhl teoretické úrovně porozumění, zdrženlivě konstatuje, že teorie a její prvky sice ovlivňují interpretaci při aktuální reflexi výuky, ale vliv teorie není př́liš uvědomovaný - respondent se víc soustřed'uje na uvádění praktických doporučení k jednání. Teprve při následném rozhovoru a vysvětlování dalších souvislostí si začíná „uvědomo- 
vat spojení mezi těmito doporučeními a uvedenými teoriemi. Považujeme to za př́klad redukované úrovně teorie" (Korthagen et al., 2011, s. 185).

Domníváme se, že v uvedené pasáži Korthagen nepřímo poukazuje na problém uplatnění teorie při sdílení znalostí v profesním společenství s ohledem na jeho tacitní složku (srov. Švec, 2009). Švec v citované stati (s. 33) upozorňuje na to, že sdílení znalostí se často v praxi děje neuvědoměle, přebíráním tacitních vzorců jednání, zatímco akademické znalosti anebo doporučení cvičných učitelů se přitom uplatňují jen málo nebo vůbec ne. Empirické nálezy (Feiman-Nemser \& Beasley, 2007) však ukazují, že tento problém lze překonávat ve společných diskusích o výuce mezi adeptem učitelství, fakultním didaktikem (jako nositelem teoretického pohledu) a cvičným učitelem. Přitom se mezi nimi utváří společný profesionální jazyk, který je $\mathrm{v}$ bezprostředním kontaktu s praxí, ale je zasazený do kontextu teoretických poznatků. Oproti Korthagenově pojetí je zde více zdůrazněna role poznatků, které do společné diskuse vnáší teoretik (napřs. fakultní didaktik či oborový specialista) a zkušený praktik (cvičný učitel). Při odhalování důležitých momentů praxe se tedy do takové míry nespoléhá jen na studentovu zkušenost ${ }^{3}$.

Společný integrující jazyk, který přiléhavě reflektuje praxi, ale zároveň se opírá o poznatkovou strukturu teorie, je zřejmě tím nástrojem, který propojuje všechny tři úrovně modelu GST. Nadto do značné míry řeší i výše zmíněný problém vztahů mezi subjektivní učitelovou teorií ( $\mathrm{s}$ malým $t$ ) a velkými Teoriemi (s velkým T). Role „velkých“ teorií zde spočívá v jejich pravidlech kodifikovaných vědeckou kulturou - především v tom, že vznášejí nároky na precizaci pojmů profesního jazyka, na jejich jednoznačnost a logické uspořádání. A co je snad nejdůležitější: podporují argumentování a zdůvodňování úsudků nebo soudů o realitě výuky. Snaha správně argumentovat a zdůvodňovat s oporou o realitu totiž stojí v samých základech teoretického myšlení: z ní vyrůstá jak požadavek terminologické jasnosti, tak potřeba systematického výzkumu praxe. Právě proto může být skutečně dobrá teorie „praktická“ - je to vlastně jen způsob myšlení praktiků dotažený kulturou k relativní dokonalosti.

Korthagenova (konstruktivistická) teorie profesního učení zdůrazňuje zkušenost studenta a z ní vzešlé potřeby. Při utváření této zkušenosti ovšem zůstává otázkou, zda je student vůbec schopen identifikovat tyto potřeby. Výzkumy začínajících učitelů ukazují, že jejich ability to notice (schopnost všimnout si) je velmi omezená. Často nejsou schopni ani popsat reálné dění ve školní třídě; kromě toho se soustřed'ují především na sebe sama v roli učitele; až mnohem později na obsah a ještě později na žáky. 
V těchto úvahách však znovu přichází ke slovu problém obsahu a učiva. Teorie pro praktické použití ve výuce nemůže obejít problematiku práce učitele s učivem, a tedy i jeho znalost oboru, kterému vyučuje. Řada výzkumů realizovaných v různých oborech vzdělávání (např. Lloyd \& Wilson, 1998; Haimes, 1996; Stein, Baxter, \& Leinhardt, 1990; McGraw, 1987; Gudmundsdottir \& Shulman, 1987) přesvědčivě prokázala, že učitelova znalost oboru ovlivňuje jak obsah, tak procesy výuky. Jinak řečeno, znalost oboru má zásadní vliv na to, co a jak učitel vyučuje. Obor na úrovni substantivních a syntaktických struktur je ale Teorií $s$ velkým $T^{4}$. Na rozdíl od znalosti tvůrce vědeckého poznání v oboru se od učitele očekává, že bude v procesech zprostředkování oborového poznání prokazovat tzv. epistemickou kompetenci, kterou Štech charakterizuje jako schopnost „iniciace do metody myšlení oboru“ (2004, s. 62). Tato epistemická kompetence je předpokladem pro psychodidaktickou transformaci, tj. pro to, „... jak jsou jednotlivé problémy, témata a pojmy organizovány, reprezentovány a adaptovány s ohledem na zájmy a schopnosti žáků a prezentovány ve výuce“, pro „ty nejúčinnější analogie, ilustrace, př́iklady, vysvětlení, slovní demonstrace, způsoby znázorňování a formulování tématu, které je učiní srozumitelnými pro jiné..." (Shulman, 1987, s. 8-9).

V přípravném vzdělávání učitelů je proto jedním ze zásadních úkolů nastartování procesů rozvoje této epistemické kompetence. Štechův poukaz na iniciaci do metody myšlení oboru je přitom rozumné chápat široce jako nárok na dostatečně hluboké žákovo porozumění tomu, co se ve výuce učí. Korthagenův výklad modelů GST a ALACT tyto otázky netematizuje. Se znalostmi oboru jakožto znalostmi Teorie s velkým T autoři explicitně nepracují, resp. v obecné rovině k nim zaujímají zdrženlivý anebo neujasněný postoj. Toto lze považovat za otázku otevřenou k dalšímu řešení.

\subsection{Význam reflexe v učitelově profesním rozvoji - vyprázdněnost s ohledem na učivo?}

Za jednu z výrazných charakteristik knihy považujeme fakt, že ačkoli se v některých pasážích autoři odvolávají na poznatky z oborové výuky, konkrétně z matematiky, celkové pojetí knihy je obecnější; oborově didaktickému hledisku se autoři nijak zvlášt' nevěnují. Pro čtenáře to může být výzva k vlastnímu uvažování o aplikacích do oborového, resp. předmětového pohledu.

4 A to, i když vezmeme v úvahu, že učitelova znalost oboru je vždy interpretací na základě učitelova přesvědčení/víry (beliefs about the subject matter; viz např. Gudmundsdottir, 2006). 
Přitom se zřejmě neubrání otázce, kde vlastně spočívají hlavní př́nosy při využití reflexe v přípravě učitelů. Čím reflexe přispívá ke kvalitě učitelské přípravy, resp. profesního rozvoje učitelů?

Korthagenova koncepce na tuto otázku odpovídá prostřednictvím dvou výše již zmíněných klíčových ideových schémat, které osvětlují hlavní funkce reflexe. Je to metodický model ALACT (Korthagen et al., 2011, s. 58 n., 74 n.) a model tří úrovní rozvoje reflektivního myšlení (GST): gestalt, schéma, teorie (Korthagen et al., 2011, s. 173 n.). Oba modely jsou postaveny na tezi, že reflektivní praxe povede k postupnému obohacování učitelových dispozic z hlediska propojení praxe s teorií.

Základním předpokladem funkčnosti obou modelů je, že reflexe je procesem, který směřuje k restrukturování vlastní zkušenosti na základě uvědomění si gestaltů intuitivně používaných k rozhodování v praxi (Korthagen et al., 2011, s. 161). To znamená, že reflexe poskytuje druhou úroveň abstrakce první úroveň vzniká intuitivně jako důsledek učení při bezprostředních reakcích s prostředím. Druhá úroveň se rozvíjí prostřednictvím reflexe s oporou o informace ve zpětné vazbě (Korthagen et al., 2011, s. 71-73). $\mathrm{V}$ pozadí těchto úvah je představa uvědomělého zlepšování (Korthagen et al. 2011, s. 72) - reflektující praktik si může uvědomit svůj dosavadní postup, vyhodnotit jeho účinnost, navrhnout jeho alternativy, posoudit je a vyzkoušet je v praxi s cílem jejího zlepšení.

To je obecná rovina pohledu na reflexi. S ohledem na naši úvodní poznámku v této kapitole je však žádoucí ji konkretizovat. Mluvíme-li o zlepšení, je na místě ptát se, co a jakým způsobem zlepšovat. Na tuto otázku Korthagen et al. v první části své knihy (2011, s. 28-29) odpovídají poukazem na výuku matematiky, kterou prezentují jako modelový příklad. To, co by bylo podle nich vhodné ve výuce matematiky zlepšit, je didaktický př́stup ve smyslu „co a jak žáky naučit“. Autoři v návaznosti na Freudenthalův „realistický př́ístup“ k vyučování matematiky zdůrazňují, že jeho východiskem je praxe a žákova zkušenost s tzv. řízeným znovuobjevováním matematické problematiky.

Didaktická stránka problému s jejím zaměřením na vzdělávací obsah/učivo, resp. obor, však $\mathrm{v}$ dalším textu zřetelně ustupuje do pozadí a převládají hlediska obecnější, pedagogická a psychologická. Přitom základní východisko je filozofické: $v$ reflexi jde o to, uvidět problém, který volá po zlepšení, a dále 
pak postupovat od perceptuální znalosti (vidèní) ke znalosti konceptuální (vědění) (Korthagen et al., 2011, s. 173-199). Jde tedy o to, jaký problém má (budoucí) učitel při reflexi uvidět a posléze nahlížet až do úrovně pojmového uchopení. Jedná se hlavně o problém vztahu mezi žákem a obsahem výuky, jak by naznačoval úvodní př́klad Freudenthalovy matematiky? Anebo se má jednat spíš o problém učitelské osobnosti a jejího vztahu k žákům, jak napovídají další kazuistiky i celková dikce výkladu, která se otázkami obsahu či učiva zabývá spíše výjimečně a okrajově?

Hypoteticky je možné uvažovat o tom, že u studentů učitelství nebo začínajících učitelů při reflexi převládá otázka „jak přežít" v sociální situaci třídy a jak porozumět svým vlastním reakcím při výuce. Tato starost je pro ně naléhavější než výzva, jak něco žáky co nejlépe naučit na základě respektu k jejich vlastnímu pojetí problému (srov. Korthagen et al., 2011, s. 195). Přitom v praxi se tyto dvě stránky učitelské práce vůbec nemusí oddělovat, a tím méně vylučovat. Žáci se totiž vždy musí učit „něčemu“ (tj. určitému obsahu, který si odnášejí jako znalost, dovednost, hodnotu apod.) „nějak“ (tj. určitým postupem výuky, který žákům umožňuje obsah uchopit). To znamená, že vztah mezi žákem a obsahem je vždy v reflexi výuky nějakým způsobem zanořen i tehdy, pokud převažuje zájem o obecnější otázky: způsoby komunikace, kvalitu sociálního klimatu, strategii budování autority učitele, podoby individualizace v podpoře procesů žákova učení, způsoby hodnocení žáků ad. V praxi ovšem ani tyto otázky nemohou být odděleny od nároku na konstrukci žákova poznávání, tj. na otázku, která nezbytně má obsahový rozměr: „co a jak se žák učí" v provázanosti s učitelovým vyučováním.

Korthagen k tomuto obsahovému rozměru nabízí jedno koncepčně zajímavé metodické řešení, které se týká i naší úvodní pochybnosti, do jaké míry se $\mathrm{v}$ koncepci realistické př́ipravy podle Korthagena zachází s obsahem, resp. učivem. Jedná se o výše již zmíněnou individuální výuku (the one-toone). Při ní se do značné míry redukují problémy s pedagogickým vedením žákovské třídy. Logicky se tedy zvětšuje prostor pro reflexi práce s obsahem a prohloubení náhledu na didaktické zvládání podpory žákovskému učení. Nicméně tuto skutečnost ani zde Korthagen nijak nezdůrazňuje a otázky navržené k reflexi zkušeností získaných vindividuální výuce jsou koncipované bez důrazu na učivo (2011, s. 85). Tím se však z reflexe vytrácí východisko, od kterého se $\mathrm{v}$ reálné výuce odvíjí vše ostatní; můžeme parafrázovat přiléhavé podobenství, které Korthagen používá v jiné souvislosti (2011, 
s. 195) - reflektovat výuku bez zřetele k jejímu obsahu je jako nejprve vztyčit zdi domu a teprve potom hloubit jeho základy 5 .

Kdybychom měli předcházející kritické úvahy shrnout a vyhrotit, Korthagenova koncepce učitelské př́pravy by se v tomto světle jevila nejspíš jako personalistická, zdůrazňující osobnostní a sociální rozvoj studentů učitelství, nikoliv didaktická. Její obecné pojetí nicméně docela dobře umožňuje posuny v jednom i druhém směru. Při posílení didaktické složky by Korthagenova koncepce byla blízká reflektivním - hospitačním - modelům učitelské přípravy, které u nás nemají zřetelně profilované a systematické zázemí v metodologii a teorii. Tuto mezeru by bylo možné zaplňovat s oporou v Korthagenově programu realistické přípravy (srov. Janík \& Slavík et al. 2011). Tím by se zároveň naskýtala př́ležitost na základě společného metodologicko-teoretického rámce úžeji propojit oborové didaktiky mezi sebou navzájem, a nadto i s obecnou didaktikou (srov. Slavík \& Janík, 2012).

\subsection{Podpora profesního učení - redukované pojetí supervize?}

Supervizi pojímají Korthagen et al. jako pomoc studentům učitelství naučit se reflektovat, anebo konkrétněji: projít jednotlivými fázemi modelu ALACT. Cílem supervize je „zvýšení reflektivnosti u studentů učitelství“ (Korthagen et al., 2011, s. 115-116). Proces supervize, charakteristiky i potřebné dovednosti supervizora přitom výrazně staví na psychologickém poradenství a na humanistické psychologii. Bylo by jistě možné diskutovat o tom, zda je volba pojmů supervize a supervizor v tomto pojetí podpory profesního učení volbou nejvhodnější (podrobněji Píšová \& Duschinská et al., 2011, s. 39-46); Korthagen et al. (2011, s. 116) ji nicméně odůvodňují pouze snahou o zjednodušení terminologie.

Supervizorem je v Korthagenově koncepci vyučující z fakulty, který provádí jak supervizi individuální, tak skupinovou. Akcent je kladen na reflexi zkušeností ze školní třídy (resp. v první fázi z individuální výuky - the oneto-one) v souladu s třemi principy nové didaktiky učitelského vzdělávání (Korthagen et al., 2011, s. 84, zde kap. 1.8). Výzkum procesů profesního učení začínajícího učitele (přehled např. Lukas, 2007, 2008; Píšová, 2005)

\footnotetext{
Komplementem k takto redukovanému přístupu mohou být tzv. obsahově zaměřené přístupy (angl. content-based či content-focused) k reflexi výuky (např. Content Focused Coaching - viz Staub, West, \& Bickel, 2003), které se v posledních letech rozvíjejí v oborových didaktikách (podrobněji viz Slavík \& Janík, 2012).
} 
ovšem ukázal, že mezi důležité aspekty profesního vývoje patří také profesní socializace. Jak upozorňují např. Boshuizenová, Bromme a Gruber (2004, s. 6), profesní učení je „jak procesem vnitřní změny jedince, tak procesem enkulturace“. Některé výzkumy z českého kulturního kontextu (např. Píšová, 1999) naznačily, že právě instituce školy a profesní komunita byly začínajícími učiteli vnímány jako zásadní problémové oblasti jejich profesní adaptace.

Je tedy otázkou, zda při uplatnění supervize v odlišných kulturních rámcích je vhodné „úzké“ zaměření podpory ve smyslu Korthagenova modelu supervize, či zda je vhodné záběr supervizora rozšiřit. V modelech učitelského vzdělávání stavějících na principech tzv. school-based teacher education by tento aspekt byl patrně jednou $\mathrm{z}$ agend spolupráce studenta učitelství $\mathrm{s}$ mentorem (či cvičným učitelem) ve škole. Jejich role je ovšem v Korthagenově knize zmíněna pouze okrajově - triadická spolupráce student-supervizor-mentor není rozpracována. ${ }^{6}$

V předcházejících kapitolách jsme uvažovali nad absencí pozornosti k problematice obsahu a učiva v modelech GST a ALACT. Ta se odráží i v navržených supervizních postupech. Poukazovali jsme na potřebu obsahově zaměrené podpory profesního učení studenta učitelství (content-based supervision; content-based coaching). $\mathrm{V}$ procesech supervize - jak jsou u Korthagena et al. rozpracovány - je ohled k učivu pojednán jen marginálně, není ani zřejmé, zda supervizor jako fakultní učitel je oborovým didaktikem, zda disponuje znalostmi oboru apod.

Je evidentní, že předchozí kritické úvahy nad vybranými aspekty realistického vzdělávání učitelů v pojetí Korthagena et al. se promítají i v koncepci pod-

6 V překladu Korthagenovy knihy používáme termíny supervizor a mentor jako synonyma v souladu s původním pojetím překládaného textu. Mohly by samozřejmě být významově odděleny a $\mathrm{v}$ tom př́padě by termín mentor odpovídal českému pojmu cvičný učitel, zatímco supervizor je pracovníkem fakulty. $\mathrm{S}$ oporou o recenzní poznámku k této části textu je užitečné dodat, že současný model praktické komponenty počátečního vzdělávání učitelů v Nizozemsku je oproti situaci popisované v Korthagenově publikaci již poněkud pozměněný. Je postaven na třech pilíŕích, jejichž působení se vzájemně doplňuje: supervizor je akademickým pracovníkem univerzity, jeho úkolem je vedení teoretické reflexe praxe (důraz na Teorii s velkým T) a hodnocení studentů; obecně (pedagogicko-psychologicky) orientovaný mentor je učitelem školy, pracuje obvykle se skupinou studentů a zaměřuje se na reflexi praxe (důraz na teorii s malým $t$ ), oborový mentor je vyučující téže aprobace jako student, pracuje se studentem převážně individuálně a hlavní agendou spolupráce je zde oborový obsah. Současné modely učitelského vzdělávání v Nizozemsku jsou popsané i v českých zdrojích (Voňková, 2011, s. 386-401; Starý et al., 2012, s. 117-124). Autoři touto cestou děkují recenzentovi/recenzentce za přesnou aktuální informaci. 
pory profesního učení studentů učitelství - v supervizi. Zároveň je ale třeba vyzdvihnout pozornost, kterou autoři věnují roli supervizora, kvalitativně odlišné od tradiční role vysokoškolského vzdělavatele učitelů, a procesům supervize, $v$ nichž jsou respektovány individuální potřeby studenta včetně tempa profesního učení. Je nutné zamyslet se nad tím, jak to vše realizovat ve struktuře učitelského vzdělávání a jaké modely učitelské př́ípravy umožňují zajistit optimální podmínky (včetně času, podpory i jejích nástrojů) pro nastartování procesů profesního rozvoje studentů učitelství.

\section{Závěrem}

Korthagen a jeho kolegové na mnoha místech knihy popisují problémy, před kterými stálo tradiční učitelské vzdělávání v Nizozemsku v 80. letech 20. století. Český čtenář však brzy zjistí, že situace, kterou autoři popisují, není nepodobná současné praxi ve vzdělávání učitelů na fakultách v České republice. Z toho lze usuzovat, že problémy tradičního učitelského vzdělávání zřejmě nejsou do té míry vázány na kontext konkrétního vzdělávacího systému. Jsou společné všem způsobům učitelského vzdělávání spadajícím do tzv. modelu technické racionality, který spočívá v tom, že se nejdříve vyučují základy oborů, pak se přednášejí metody didaktické aplikace a nakonec následuje praxe (Argyris \& Schön, 1992, s. 18). Pokud jde o možnosti efektivního propojování vzdělávací teorie s praxí, tento model zřejmě naráží na své limity a všeobecně selhává.

Korthagenova kniha nabízí k modelu technické racionality promyšlenou, propracovanou a $\mathrm{v}$ praxi již dlouho prověřovanou alternativu. Jak jsme ukázali v této studii, také tato alternativa je spojena s některými problémy. Vzhledem k omezenému rozsahu tohoto textu jsme se zamýšleli pouze nad třemi z nich. Šlo o nedocenění Teorie s velkým $T$, o vyprázdněnost reflexe $\mathrm{s}$ ohledem na učivo a o redukované pojetí supervize. Přes veškerou kritiku se domníváme - a v předcházejícím textu jsme se snažili na to upozornit - že podněty k překonávání uvedených problémů lze při vstř́ícně kritickém čtení nacházet již v Korthagenově textu.

Důvodem je zřejmě to, že hlavní složky problémů jsou v textu pojmenovány a uchopeny. To znamená, že první podstatný krok k jejich promýšlení, diskutování a řešení je učiněn. Vstřícně kritický čtenář může docela dobře polemizovat s Korthagenovými důrazy na to či ono, ale zároveň ocení Korthagenovu nabídku analýzy problémů a rozboru jejich hlavních složek. Právě proto 
může být kritika této knihy dobře opřena ve svém předmětu. Může totiž ke Korthagenovým důrazům hledat alternativy a řešit slabší místa jeho koncepce s využitím současných perspektivních př́ístupů, jak jsme naznačili. Přesnější vymezení problémů, které považujeme za klíčové, a jejich konkretizace s návrhy operacionálních řešení budiž předmětem pozornosti (nejen našich) dalších textů.

\section{Autoři}

doc. PaedDr. Jan Slavík, CSc., doc. PhDr. Tomáš Janík, Ph.D., M.Ed., Mgr. Petr Najvar, Ph.D., doc. PhDr. Michaela Píšová, Ph.D., M.A., Institut výzkumu školního vzdělávání PdF MU, Poříčí 31, 60300 Brno, e-mail: tjanik@ped.muni.cz

\section{Literatura}

Argyris, C., \& Schön, D. (1992). Theory in practice: Increasing professional effectiveness. San Francisco: Jossey-Bass.

Boshuizen, H. P. A., Bromme, R., \& Gruber, H. (2004). Introduction: On the long way from novice to expert and how travelling changes the traveller. In H. P. A. Boshuizen, R. Bromme, \& H. Gruber (Eds.), Professional learning: Gaps and transitions on the way from novice to expert (s. 3-7). Dordrecht: Kluwer Academic Publishers.

Dann, H. D., Müller-Fohrbrodt, G., \& Cloetta, B. (1981). Sozialisation junger Lehrer im Beruf. Praxisschock drei Jahre später. Zeitschrift für Entwicklungspsychologie und Pädagogische Psychologie, 13(3), 251-262.

Feiman-Nemser, S., \& Beasley, K. (2007). Discovering and sharing knowledge: Inventing a new role for cooperating teachers. In D. Carroll, H. Featherstone, J. Featherstone, S. FeimanNemser, \& D. Roosevelt (Eds.), Transforming teacher education: Reflections from the field (s. 139-160). Cambridge, MA: Harvard Education Press.

Freudenthal, H. (1978). Weeding and sowing: Preface to a science of mathematical education. Dordrecht: Reidel.

Fuller, F. F., \& Bown, O. H. (1975). Becoming a teacher. In K. Ryan (Ed.), Teacher education, the 74th yearbook of the National Society for the Study of Education (s. 25-52). Chicago: University of Chicago Press.

Gudmundsdottir, S., \& Shulman, L. (1987). Pedagogical content knowledge in social studies. Scandinavian Journal of Educational Research, 31(2), 59-70.

Haimes, D. H. (1996). The implementation of a „Function“ approach to introductory algebra: A case study of teacher cognitions, teacher actions, and the intended curriculum. Journal of Research in Mathematics Education, 27(5), 582-602.

Hinsch, R. (1979). Einstellungswandel und Praxisschock bei jungen Lehrern, eine empirische Längsschnittuntersuchung. Weinheim: Beltz.

Janík, T., \& Minaříková, E. et al. (2011). Video v učitelském vzdělávání: teoretická východiska, aplikace, výzkum. Brno: Paido. 
Janík, T. (2005). Znalost jako klíčová kategorie učitelského vzdělávání. Brno: Paido.

Janík, T., Slavík, J., Najvar, P., Hajdušová, L., Hesová, A., Lukavský, J., Minaříková, E., Píšová, M., \& Švecová, Z. (2011). Kurikulární reforma na gymnáziích: od virtuálních hospitací $k$ videostudiím. Praha: VÚP.

Kasáčová, B. (2006). Reflexie študentov učitel'stva z pohladu kvalitatívneho výskumu. Pedagogika, 56(1), 58-79.

Korthagen, F. et al. (2011). Jak spojit praxi s teorií: Didaktika realistického vzdělávání učitelů. Brno: Paido.

Lloyd, G. M., \& Wilson, M. S. (1998). Supporting innovation: The impact of a teacher's conceptions of functions on his implementation of a reform curriculum. Journal for Research in Mathematics Education, 29(3), 248-274.

Lukas, J. (2007). Vývoj učitele: přehled relevantních teorií a výzkumů (část 1). Pedagogika, 56(4), $364-379$.

Lukas, J. (2008). Vývoj učitele: přehled relevantních teorií a výzkumů (část 2). Pedagogika, 57(1), 36-49.

Lukášová-Kantorková, H. (2003). Učitelská profese v primárním vzdělávání a pedagogická príprava učitelü: teorie, výzkum, praxe. Ostrava: Pedagogická fakulta OU.

Maňák, J. (2011). K problému teorie a praxe v pedagogice. Pedagogická orientace, 21(3), 257-271.

McGraw, L. (1987). The anthropologist in the classroom: A case study of Chris, a beginning social studies teacher. Stanford: Stanford University, School of Education.

Minaříková, E., \& Janík, T. (2012). Profesní vidění učitelů: od hledání pojmu k možnostem jeho uchopení. Pedagogická orientace, 22(2), 181-204.

Píšová M., \& Duschinská, K. et al. (2011). Mentoring v učitelství. Praha: Pedagogická fakulta UK.

Píšová, M. (1999). Novice teacher. Pardubice: Sci. Pap. University of Pardubice, Series C, Supplement 1.

Píšová, M. (2005). Klinický rok: procesy profesního rozvoje studentů učitelství a jejich podpora. Pardubice: Univerzita Pardubice, Fakulta humanitních studií.

Schmidt, H. G., \& Boshuizen, H. P. A. (1992). Encapsulation of biomedical knowledge. In D. A. Evans \& V. L. Patel (Eds.), Advanced models for cognition or medical training and practice (s. 265-282). New York: Springer.

Schön, D. A. (1983). The reflective practitioner. New York: Basic Books.

Shulman, L. S. (1987). Knowledge and teaching: Foundations of the new reform. Harvard Educational Review, 57(1), 1-22.

Slavík, J., \& Janík, T. (2012). Kvalita výuky: obsahově zaměřený př́ístup ke studiu procesů vyučování a učení. Pedagogika, 62(3), 262-287.

Spilková, V., \& Vašutová, J. et al. (2008). Učitelská profese v měnících se požadavcích na vzdělávání. Praha: PedF UK v Praze.

Spilková, V. et al. (2004). Současné proměny vzdělávání učitelů. Brno: Paido.

Starý, K., Dvořák, D., Greger, D., \& Duschinská, K. (2012). Profesní rozvoj učitelů. Podpora učitelů pro zlepšování výsledků žáků. Praha: Karolinum.

Staub, C. F., West, L., \& Bickel, D. P. (2003). What is content-focused coaching? In L. West \& F. C. Staub (Eds.), Content-focused coaching: Transforming mathematics lessons (s. 1-17). Portsmouth: Heinemann. 
Štech, S. (2004). Psychodidaktika jako obrat k účinnému vyučování. Pedagogika, 54(1), 58-63.

Stein, M. K., Baxter, J. A., \& Leinhardt, G. (1990). Topic-matter knowledge and elementary instruction: A case from functions and graphing. American Educational Researcher, 27(4), 639-663.

Švec, V. (1999). Pedagogická př́prava budoucích učitelů: problémy a inspirace. Brno: Paido.

Višňovský, E., Kaščák, O., \& Pupala, B. (2012). Pedagogický dualizmus teoretického a praktického: historické pozadie a súčasné ilúzie. Pedagogická orientace, 22(3), 305-335.

Voňková, H. (2011). Příprava učitelů a pedagogická praxe v Nizozemsku. In S. Bendl et al., Klinická škola: místo pro výzkum a praktickou př́pravu budoucích učitelů. Praha: Univerzita Karlova, Pedagogická fakulta.

Zeichner, K., \& Tabachnik, B. R. (1981). Are the effects of university teacher education washed out by school experience? Journal of Teacher Education, 32(3), 7-11.

\title{
Between practice and theory in teacher education: notes on the Czech translation of Korthagen et al.'s book
}

\begin{abstract}
This theoretical paper follows the publication of the Czech translation of the book by F. A. J. Korthagen et al. Linking practice and theory: The pedagogy of realistic teacher education. The paper consists of two parts. In the first part, the key (leading) ideas of Korthagen's approach are introduced; the text is descriptive without the ambition to provide a critical analysis. Such analysis is the topic of the second part of the text. The authors revisit some of the ideas of Korthagen's approach, analyse them and discuss them in a wider context of some newer approaches. They focus on three problem areas: (1) The nature of the relationship between practice and theory - underestimating Theory with capital T? (2) The importance of reflection in teachers' professional development - deemphasising content? (3) Supporting professional learning - a limited view on supervision? Towards the end of the paper, the authors discuss how the presented ideas could inspire the practice of teacher education in the Czech Republic.
\end{abstract}

Keywords: practice, theory, teacher education, reflection, instruction, supervision 